\title{
International Co-operation between Firms on Innovation and R\&D: Empirical Evidence from Argentina and Spain
}

\author{
Mónica Edwards-Schachter', Elena Castro- Martínez², Ignacio Fernández-de-Lucio³
}

\begin{abstract}
This paper examines co-operative innovation and Research and Development (R\&D) behaviour between Argentine and Spanish firms. Based on theoretical perspectives from the literature, we present empirical evidence obtained from 104 firms of patterns of cooperation in several processes and out-puts, highlighting firm characteristics, the motives of the collaborating parties, types of partners, R\&D and innovation activities, leadership, and obstacles to cooperation. Our results reveal that the determinants of success differ considerably among countries depending on the sector, the firm specific characteristics and funding. These differences have important implications for public policy and instruments to support R\&D and innovation activities.
\end{abstract}

Keywords: R\&D; international cooperation; technological cooperation; innovation; cooperation patterns; argentine firms; spanish firms.

\footnotetext{
1,2,3 INGENIO (CSIC - UPV), Universitat Politècnica de València, Ciudad Politécnica de la Innovación (CPI), Camino de Vera s/n, Ed. 8E, $4^{\circ}$ P. 46022Valencia (Spain), TE: + 34963877048 Fax + 34 963877991.Email:moed@ingenio.upv.es; ecastrom@ingenio.upv.es; ifernand@ingenio.upv.es
} 


\section{Introduction}

Knowledge creation and networking are increasingly at the international level and are accompanying the emergence of global patterns of R\&D and innovation (Archibugi and lammarino, 2002; Narula and Duysters, 2004; Edler, 2007, 2008). Current evidence on R\&D flows suggests that the global innovation environment has changed due to more intense global competition and the need to innovate more quickly and on a different scale (Niosi, 1999; Carlson, 2006; Edler, 2008). The internationalisation of R\&D and innovation stems from: the complexity of global competition with the advent of new, more differentiated products and producers; institutional change as a result of liberalization; the impact of information and communication technologies (ICT); transformations in markets, competition and industrial organization; adjustments in corporate strategies and business models, among others (Ernst, 2005; OECD, 2008). The increasing costs and risks associated with technological innovation have led firms to see cooperation as the best option in many instances, particularly in capital- and knowledgeintensive sectors (Narula and Duysters, 2004). In words of De la Mothe and Link (2002:266) "Technological competition has increasingly become global in scope and related technology life cycles have shortened; firms have correctly responded to this new order by implementing multifaceted innovation strategies that reflect a new philosophy about the interdependence of competing firms. Speed in innovation is increasingly becoming the strategic benchmark upon which competitive survival will be benchmarked. As such, firms are partnering with other firms, organizations and institutions in an effort to survive".

The available literature on global technological collaborations is more fragmented and is not easily identifiable. Apart from some 'commercial' databases, mainly focused on the biotechnology and information technology sectors, there are few databases (Hagedoorn et al., 2000). Information obtained from the MERIT-CATI database -one of the few still existing databases- shows that the strategic alliances for technological purposes have substantially increased since 1970 to present, being particularly relevant in crucial technological areas such as biotechnology, new materials and information technologies (Hagedoorn 1996, 2002; Archibugi and lammarino, 2002). Hagedoorn (2002) shows that R\&D partnering is 'a game' dominated by companies from the world's most developed economies. Technological alliances between countries of the Triad (United States, European Union and Japan) have grown 170\% between 1980 and 1998 with a clear dominance of United States in major high-tech industries (Hagedoorn, 2002; Niosi and Reid, 2007). At the present and according a recent OECD report the propensity to collaborate on innovation with partners abroad varies widely among countries, ranking from less than $2 \%$ of all firms in Korea, Japan and Australia to more than $8 \%$ in Canada and New Zealand. Among European firms, for example, the share of collaboration with partners in a different country within Europe ranged from less than $2 \%$ in Italy, Rumania and Spain to more than $12 \%$ in Denmark, Finland and Belgium (OECD, 2008, 2009). In developing countries, as emerges from in depth reading of a review of the literature promoted by UNCTAD firms are only marginally involved in such collaborations (Pietrobelli 1996; Ernst, 2005).

To our knowledge and despite the extensive empirical literature on inter-firm cooperation, there is little information and few studies on cooperation in both Spain and Argentina. Several authors such as Agüero et al. (1999), Bayona et al. (200I), Hidalgo Nuchera and Albors Garrigós (2004a, b) and Heijs and Buesa (2006) in Spain, and Albornoz and Estébanez (1998) in Argentina have carried out studies, but mostly focused on cooperation at the national level. This may be the first investigation specifically targeting inter-firm cooperation in both countries.

In this context, this paper intend to explore the extent to which Argentine and Spanish firms engage in cooperative R\&D behaviour and aims to shed light on the characteristics of such relationship, being its principal objectives:

-to detect and characterize cooperation relationships on innovation and R\&D between Spanish and Argentine firms,

- to analyze patterns and firm characteristics that influence firms' decision to cooperate with foreign partners on their innovation and R\&D activities

- to identify barriers which could influence inter-firm cooperation in both countries. 


\section{Theoretical background and literature review}

Archibugi and Michie (1995) have distinguished three modes of internationalisation on innovation and R\&D:

a) International R\&D cooperation between partners in more than one country to generate new scientific knowledge and technological know-how, whereby each partner retains its own institutional identity and ownership remains unaltered; b) International generation of knowledge and innovations carried out by multinational enterprises which create innovations across borders by building up research networks including the establishment of new R\&D units in the host country or the acquisition of foreign R\&D units, i.e. Foreign Direct Investment (FDI) in R\&D; and c) International exploitation of innovation, know-how and technologies through means of trade, granting of licenses and patents, reverse engineering etc. (technological collaborations). But, what do we understand by "international collaborations", including innovation cooperation activities?

There are several definitions of international cooperation involving R\&D and innovation, which are considered to be the "the relation between different organizations based on innovation with a certain content of R\&D" (Hagedoorn et al., 2000). In general, international cooperation on $R \& D$ and innovation is seen as a strategic decision that implies the transfer of knowledge between partners located in different countries (Barajas and Huergo, 2006). The decision to cooperate goes beyond the selection of a foreign partner and involves the company becoming familiarized with an environment that is different from its habitual one, which may have implications for the management of innovation resources and activities.

Although aspects such strategic technological alliances became the focus of considerable theoretical and empirical attention during the 1980s and 1990s, literature is fragmented and heterogeneous (Archibugi and lammarino, 2002; Tether, 2002). There is no established theory, either in management (at the firm level) or industrial and evolutionary economics (at the industrial level) to explain the present wave of international technological cooperation. Nevertheless and following the works of Lundin et al. (2004) it is possible to establish a global scheme for analysis, taking into account the confluence of three theoretical scopes: internationalisation, cooperation and innovation (including R\&D, technological and non technological innovations).
Various authors have provided extensive reviews on the phenomena of cooperation and establishment of international alliances, analyzing their evolution from 1960 (Hagedoorn, 2002; Hagedoorn and Osborn, 2002; Narula and Duysters, 2004). Research literature focuses on four areas: the reasons for cooperation; selection of partners; alliance management (control, conflicts, fulfillment of the alliance objectives, leadership); results and impact cooperation (Bayona, García-Marco and Huerta, 200I; Vonortas et al., 2003; Lundin et al., 2004). Research on understanding international inter-firm cooperation on R\&D and innovation can be grouped into the following representative strands:

- Market-power theory (MPT), focused on cooperation as mediator instrument between market and firms for improving their competitive success (Porter, 1980; Child and Faulkner, 1998).

- Transaction Cost Theory, related to the cost of participating in a market and making an economic exchange (Teece, 1987; Brockhoff, 1992);

- Strategic Management Theory, focused on the relation between technological cooperation and corporate strategy (Dodgson, 1992; Child and Faulkner, 1998);

- Industrial Organization Theory, focused on the study of firms' strategic behaviour, and the structure of markets and their interactions, paying attention to the generation of spillovers (Gassmann and von Zedtwitz, 1999; Hagedoorn et al., 2000).

Other theoretical perspectives include Social Exchange Theory (Das and Teng, 2002), Resource-Based Theory (Conner and Prahalad, 1996; Combs and Ketchen, 1999) and game theory (Sanna-Randaccio and Veugelers, 200I; Eriksson, 2007; Binenbaum, 2008). 


\section{International cooperation}

\section{Cooperation on RandD and innovation}



\section{Focus of our research}

Figure I. Analytical scheme of international cooperation on innovation and R\&D (including technological and non-technological innovation). Source: adapted from Lundin et al. (2004, p. 7)

Table I provides a brief explanation about the principal aspects considered by the literature on of international cooperation on innovation and R\&D:

\begin{tabular}{|c|c|}
\hline Topics & Researchers \\
\hline $\begin{array}{l}\text { Firm size. } \\
\text { A Ithough there is no consensus in the literature, most authors } \\
\text { assume a positive correlation between firm size and cooperation } \\
\text { in } R \& D \text {, and innovation intensity. }\end{array}$ & $\begin{array}{l}\text { M olero (1998); B ayona et al. (2001); Hidal go } \\
\text { Nuchera and A lbors Garrigs }(2004 a, \text { b); } \\
\text { Narula (2004) }\end{array}$ \\
\hline $\begin{array}{l}\text { Firm age and experience } \\
\text { Previous experience and age of the firm are positively correlated } \\
\text { to participation in cooperation on } R \& D \text { and innovation. }\end{array}$ & M olero (1998); F ritsch and Lukas (2001) \\
\hline $\begin{array}{l}\text { M otives for cooperation. } \\
\text { Hagedoorn (1993) lists the motives for cooperation as: } \\
\text { (1) related to basic and applied research and some general } \\
\text { characteristics of technological development } \\
\text { (minimizing and sharing of uncertainty in } R \& D \text {, } \\
\text { reduction in and sharing of costs of } R \& D \text { ). } \\
\text { (2) related to real innovation processes (capturing partner } \tilde{\text { S }} \\
\text { tacit knowledge of technology, technology transfer, } \\
\text { technological leapfrogging, shortening the product life } \\
\text { cycle, and the period between invention and market } \\
\text { introduction). } \\
\text { (3) related to market access and opportunities } \\
\text { (internationalisation and entry to foreign markets, new } \\
\text { products and markets, expansion of product range).. }\end{array}$ & $\begin{array}{l}\text { Hagedoorn (1993), B ayona et al. (2001); } \\
\text { N ooteboom (1999); Narula (2002, 2004); } \\
\text { Tether (2002); Vonortas et al. (2003); } \\
\text { M ontoro et al. (2006) }\end{array}$ \\
\hline
\end{tabular}




\begin{tabular}{|c|c|}
\hline $\begin{array}{l}\text { Activity sector and technological intensity. } \\
\text { In the case of small and medium sized enterprises (SM E), the } \\
\text { extent and intensity to which they can use collaboration varies by } \\
\text { the maturity of their primary technologies. Some firms operate in } \\
\text { sub-sectors that are increasingly paradigmatic and mature, others } \\
\text { are pre-paradigmatic and nascent. }\end{array}$ & $\begin{array}{l}\text { M olero (1998); Hagedoorn (1993); N arula } \\
\text { (2002); Lundin et al. (2004) }\end{array}$ \\
\hline $\begin{array}{l}\text { Cooperation agents } \\
\text { Include the type of partner (other firm, university, research } \\
\text { institute) and the reasons for their selection. } \\
\text { Cooperation may be horizontal (between competitors) or vertical } \\
\text { (customer, supplier), intra or inter-sectoral. }\end{array}$ & $\begin{array}{l}\text { Dussauge et al. (2000); Fritsch and L ukas } \\
\text { (2001); L undin et al. (2004); H eijs and B uesa } \\
\text { (2006); M ontoro et al. (2006) }\end{array}$ \\
\hline $\begin{array}{l}\text { Agreement types } \\
\text { Formal, informal, joint venture, equity and non-equity } \\
\text { agreements, etc. }\end{array}$ & $\begin{array}{l}\text { Hagedoorn (1990); N ooteboom (1999); } \\
\text { Lundin et al. (2004) }\end{array}$ \\
\hline $\begin{array}{l}\text { Cooperation process } \\
\text { Includes management of the agreement, initiation of contacts } \\
\text { between firms, project management, organizational climate, } \\
\text { leadership, etc. }\end{array}$ & $\begin{array}{l}\text { Hagedoorn (1993); K hanna et al. (1998); } \\
\text { Nooteboom (1999); L pe z (2008); Hoffman } \\
\text { and Schlosser (2001); G erwin and M eister } \\
\text { (2002); Kauser and Shaw (2004) }\end{array}$ \\
\hline $\begin{array}{l}\text { Regulatory conditions and funding } \\
\text { Governments can facilitate (or not) international collaboration } \\
\text { through financial support and easing of the regulatory conditions } \\
\text { that restrict the potential for cooperation. M ost international } \\
\text { activities take place within established international networks and } \\
\text { programmes. In general, there are more multilateral programmes } \\
\text { and international instruments are not integrated with national } \\
\text { strategies }\end{array}$ & $\begin{array}{l}\text { Nooteboom (1999); Hidalgo Nuchera and } \\
\text { A lbors Garrigs- (2004a, b); L undin et al. } \\
\text { (2004); Heijs and Buesa (2006) }\end{array}$ \\
\hline $\begin{array}{l}\text { Barriers to cooperation } \\
\text { There are several barriers: financial restrictions, lack of suitable } \\
\text { human resources, problems of appropriability of the results } \\
\text { among partners, additional costs and time of cooperation, finding } \\
\text { suitable partners, coordination/communication problems, conflicts } \\
\text { of different interests, etc. }\end{array}$ & $\begin{array}{l}\text { Dodgson (1992); Hladik (1988); Hagedoorn } \\
\text { (1993); Hidalgo N uchera et al. (2006); Tiwari } \\
\text { and Buse (2007); Teixeira et al. (2008) }\end{array}$ \\
\hline $\begin{array}{l}\text { Results and impact of cooperation } \\
\text { Economic and technological improvements, including the effects } \\
\text { of technological spillovers, the development of new products, the } \\
\text { development of/improvements to new or existing processes, } \\
\text { exploitation of complementary resources, acquisition/creation of } \\
\text { new knowledge, etc. }\end{array}$ & $\begin{array}{l}\text { Cassiman and V eugelers (1999); Hagedoorn } \\
\text { and Schakenraad (1994); Criscuolo (2004); } \\
\text { Kauser and Shaw (2004); H eijs and Buesa } \\
\text { (2006) }\end{array}$ \\
\hline
\end{tabular}

Table I. Principal issues related to international cooperation on R\&D and innovation 
There were some limitations in this study considering the innovation landscapes in the world and in both countries. We must recall the general low level of resources devoted to $R \& D$ and innovation in both countries. Thus, the amount of R\&D expenditures as part of GDP is around $1.3 \%$ in Spain (lower than those of most European countries) and $0.5 \%$ in Argentina (Table 2). National Innovation Surveys in both Spain and Argentina puts in evidence similar characteristics in relation to the firms' innovation behaviour and strategies: a high number of companies which declares to make R\&D that contrasts with a low magnitude in their innovation efforts. In Argentine firms the dominant innovation strategy is the external knowledge acquisition while in Spanish firms prevail the in-house R\&D activities. A recent research realised by Vega-Jurado et al. (2008) with a sample of 329 Spanish manufacturing firms shows that the development of inhouse R\&D activities is the principal innovation strategy, while R\&D contracting and cooperation with external agents has not significant effect on firm's innovative performance. In addition, inter-firm co-operations are reported to encounter high failure rates (Dans and Teng, 2000; Sivadas and Dwyer, 2000; Bönte and Keilbach, 2005). Das and Teng (2000) account that their literature survey, comprised of 16 empirical studies, leads to the conclusion that less than half of the alliances studied can be said to have performed satisfactorily.

(1) L ow level of innovation resources. The amount of $R \& D$ expenditures as part of GDP is $0.5 \%$ in A rgentina and $1.3 \%$ in Spain

- Low industry financed R\&D: A rgentina: 30\% - Spain: 55\%

- Weak density relationships between the different actors of the respective $\mathrm{N}$ ational System of Innovation (NSI)

- Majority of SME and few large companies

- Little development of risk capital

- Principal innovation strategies: in A rgentina $R \& D$ acquisition (external $R \& D$ ) and in Spain in house $R \& D$

- Innovative firms in Spain cooperate over innovation less than other European countries

- Cooperation is not relevant for the majority of A rgentine firms

Table 2. Argentine and Spanish innovation landscape. Sources: INDEC (2008), INE (2009) and EUROSTAT (2010) 
Regarding these limitations and the lack of databases on inter-firm cooperation in both countries, we consider the particular case of firms that we believe have been involved in cooperation (firms that have participated in international cooperation programmes, and exporting firms). Although our analysis is related primarily to technology cooperation, we consider both technological and nontechnological innovation activities performed by the firms.

\section{Method}

We elaborated a database containing 540 innovative firms from Spain and Argentine to administer a survey which received a response rate of $20.2 \%$. A significant percentage $(47 \%)$ of the surveyed enterprises had participated in a government program called IBEROEKA, a political instrument that was introduced in 1991 to reinforce industry competitiveness in 21 lbero-American countries through scientific and technological cooperation among innovative enterprises and other actors (Hidalgo and Albors, 2004; Hidalgo et al., 2006) . Additional information on other firms was obtained from the Spanish Institute for Foreign Trade (Instituto Español de Comercio Exterior, ICEX) database. The survey was administered by mail and online and was complemented by information obtained through telephone interviews.

The questionnaire included $5 \mathrm{I}$ multi-item and closed and open-ended questions distributed in three parts, as follows:

- Part I collected data on firm background and general characteristics (size, sector and branch of activity, human resources, etc.).

- Part 2 asked about the firm's general experience with cooperation on innovation and R\&D in general

- Part 3 collected data on cooperation relationships between Spain and Argentina, focusing on in-puts, out-puts and the cooperation process (motives of the collaborating parties, cooperation modalities, types of partners, previous experience of cooperation with firms, universities, research institutes and other agents, forms of agreements, expected outcomes, investments and public support for innovation activities, results of cooperation, etc).

\section{Results}

In this study we firstly performed a descriptive analysis of the sample. Secondly we have used statistical methods to analyze the relationship between variables. Considering the type of variable, we use non-parametric analysis ( $U$ Mann-Withney and Kruskal-Wallis tests) when the variable is quantitative and Pearson's chi-square if it is qualitative (see Annex).

\section{Firms' profile}

Majority of Spanish companies claimed to be innovators (53 out of 56 firms, 94.6\%) and were in favour of cooperation (5I or $91.1 \%$ ). The percentage of Spanish firms that cooperated with other firms in the last three years (39 firms) was 70\%. The results for Argentina are less favourable to cooperation: 20 out of 48 firms are innovators (4I.7\%) and 21 had cooperated with other companies (43.8\%). Only 17 Argentine companies had cooperated over R\&D and innovation with Spanish companies, which is only just over a third part of the companies in our sample (35.4\%) (Figure 2). $80.4 \%$ (45 companies) are involved in exporting, with the percentage similar for both countries (12 out of 17 Argentine firms and 33 out of 39 Spanish firms, $70.6 \%$ and $84.6 \%$ respectively). 


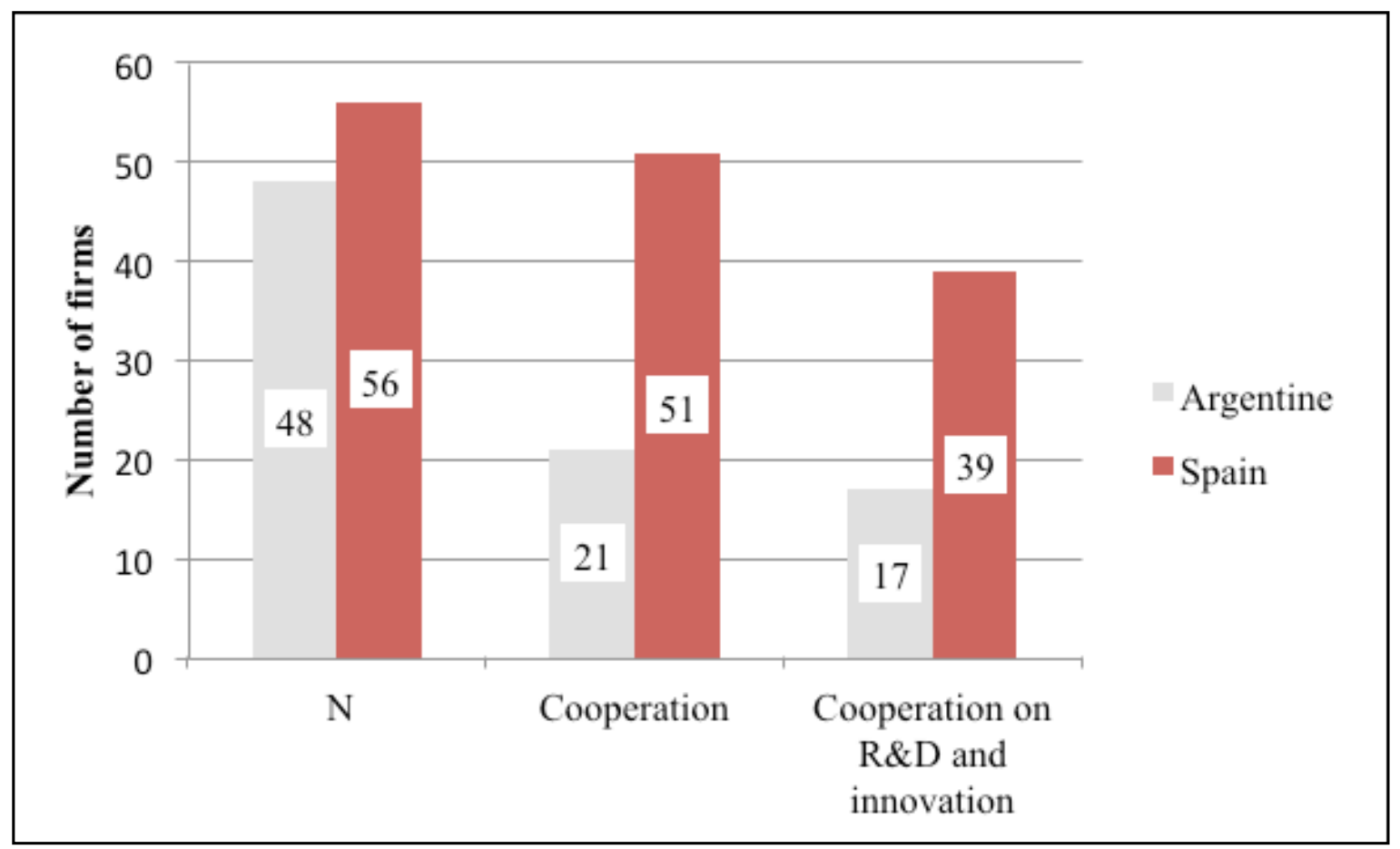

Figure 2. Cooperation between Argentine and Spanish firms

\section{Firm size}

In particular, the segment of small firms fits the knowledge profile of the Spanish firms, being SME the main collaborators: 14 out of 17 Argentine companies (82.4\%) and 26 out of 39 Spanish firms (66.7\%). None of the large Argentine companies in the sample had been involved in cooperation and only 5 from the Spanish sample (8.9\%) had collaborated. These results are in contrast to those in the literature, which highlights big companies as being the main collaborators based on presence in the market and high level of R\&D intensity (Hagedoorn and Schakenraad, 1994; Vonortas, 1997; Fritsch and Lukas, 200I; Tether, 2002; Cassiman and Veugelers, 2006). Also empirical work on Spain shows similar results (Fonfría, 1998; Bayona et al., 200 I; López, 2008). In general, the state-of-the-art review evidences that relation size-innovation depends of the innovation activity. Thus, great firms predominate in the activities with mature and relatively stable technologies. Nevertheless, smaller companies tend to concentrate in clusters geographic to take advantage of synergies in technologies of faster evolution. Most authors assume a positive correlation between firm size and cooperation in R\&D, and innovation intensity (Molero, 1998; Bayona et al., 200I; Hidalgo Nuchera and Albors Garrigós, 2004a and b; Narula, 2004). As it shows in the table (Annex) for the total sample size of firm is related with companies that transfer technology from Spain to Argentina $(p<0 . I)$. In the case of Argentina, receiving subsidies from the state is related to size $(p<0.1)$.

\section{Age}

Previous experience and age of the firm are positively correlated to participation in cooperation on R\&D and innovation (Molero, 1998; Fritsch and Lukas, 200I). In general younger companies are more keen to cooperate: more than have of those in the sample had been established for less than 20 years and a third had been in existence for only 10 years. The highest frequency of cooperation is among companies aged 20 to 50 years old, and percentage involved in collaboration among companies more than 50 years old is only $9.1 \%$ (see Table 3). In the case of Spanish firms the age of the company is different according to the cooperation frequency $(p<0 . I)$ (see Annex). 


\begin{tabular}{|l|l|c|c|c|c|}
\hline \multicolumn{1}{|c|}{$\begin{array}{c}\text { A ge } \\
\text { [year] }\end{array}$} & $\begin{array}{c}\text { A rgentine } \\
\text { firms } \\
\mathrm{N}=17\end{array}$ & $\begin{array}{c}\text { Spanish firms } \\
\mathrm{N=39}\end{array}$ & $\begin{array}{c}\text { Total } \\
\mathrm{N}=56 \\
\text { Frequency }\end{array}$ & $\%$ \\
\hline Valid & M inor of 5 & 4 & 4 & 8 & 14.5 \\
\hline & 5 to 10 & 3 & 9 & 12 & 21,8 \\
\hline & 10 to 20 & 5 & 5 & 10 & 18.2 \\
\hline & 20 to 50 & 5 & 15 & 20 & 36.4 \\
\hline & 50 to 100 & 0 & 4 & 4 & 7.3 \\
\hline & M ore than 100 & & 1 & 1 & 1.8 \\
\hline & Total & & 1 & 55 & 98.2 \\
\hline Missing Value & \multicolumn{2}{|c|}{56} & 1 & 1.8 \\
\hline Total &
\end{tabular}

Table 3. Age of Argentine and Spanish firms

\section{Activity sector and technological intensity}

In the case of Small and Medium sized Enterprises (SME), the extent and intensity to which they can use collaboration varies by the maturity of their primary technologies. Some firms operate in sub-sectors that are increasingly paradigmatic and mature, others are pre-paradigmatic and nascent (Molero, 1998; Hagedoorn, 1993; Narula, 2002; Lundin et al., 2004). Figure 3 shows the distribution of firms according to sector of activity. ICT is the most represented sector in the sample with 24 companies $(42.9 \%$ of the sample). It is also one of the main sectors involved in IBEROEKA (CDTI, 2009. IBEROEKA's first program was CYTED (Science and Technology for the Development) launched by the Spanish Government and the Economic Commission for Latin America (CEPAL) to improve technological cooperation between firms in Spain, Portugal and Latin America (see http://www.cyted.org/).



Figure 3. Argentine and Spanish firms 
The $76.8 \%$ of the companies that have cooperated are of high and medium-high technological intensity and only $23.2 \%$ are low and low-medium intensity firms. This trend is especially strong for the Argentine firms (Table 4). This is in line with the literature on SME and innovation activity in certain sectors and technologies. Two examples of high innovation performance among SME are born globals and SME participation in the EC 7th Framework Programme (FP7), where SME outshone large companies.

\begin{tabular}{|c|c|c|c|}
\hline Technological intensity & $\begin{array}{l}\text { A rgentine firms } \\
\qquad \mathrm{N}=17\end{array}$ & $\begin{array}{c}\text { Spanish firms } \\
\qquad N=39\end{array}$ & Total $\mathrm{N}=56$ \\
\hline High and medium-high & $15(88.2 \%)$ & $28(71.8 \%)$ & $43(76.8 \%)$ \\
\hline Low and low-medium & $2(11.8 \%)$ & $11(28.2 \%)$ & $13(23.2 \%)$ \\
\hline
\end{tabular}

Table 4. Argentine and Spanish firms according their technological intensity

\section{Motives for cooperation}

\section{Motives for cooperation in general}

Hagedoorn (1993) lists the motives for cooperation as: a) related to basic and applied research and some general characteristics of technological development (minimizing and sharing of uncertainty in R\&D, reduction in and sharing of costs of R\&D); b) related to real innovation processes (capturing partner's tacit knowledge of technology, technology transfer, technological leapfrogging, shortening the product life cycle, and the period between invention and market introduction); and c) related to market access and opportunities (internationalisation and entry to foreign markets, new products and markets, expansion of product range).

In this study, the first motive is access to new markets, followed by better commercialization and distribution and the introduction of new products to the market. Other reasons include introduction of a technology new to the company and improvements to the productive process (through a new quality system, stock reduction, etc.). Access to resources and organizational improvements seem to be less important (Figure 4).

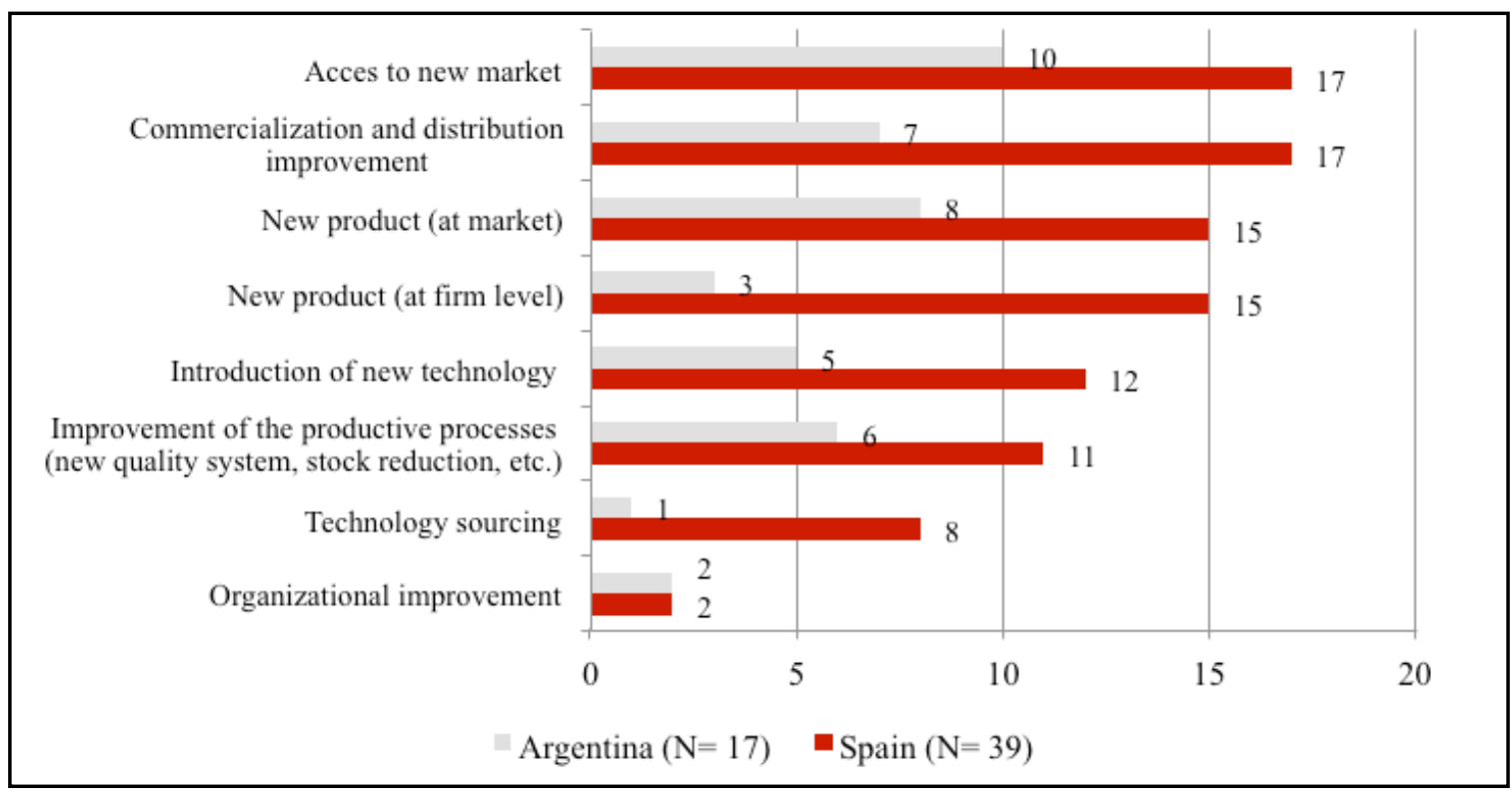

Figure 4. Motives for general cooperation between Argentine and Spanish firms $(\mathrm{N}=56)$ 


\section{Motives for cooperation over R\&D and innovation}

The first strategy is entering new markets (27 companies cited this as the main reason in order to increase sales/exports). Joint R\&D tasks, technological complementarities, technical assistance and technical problem solving are other important motives for cooperation, as a logical consequence of technological cooperation projects financed through the IBEROEKA programme (see details at Fig. 5).

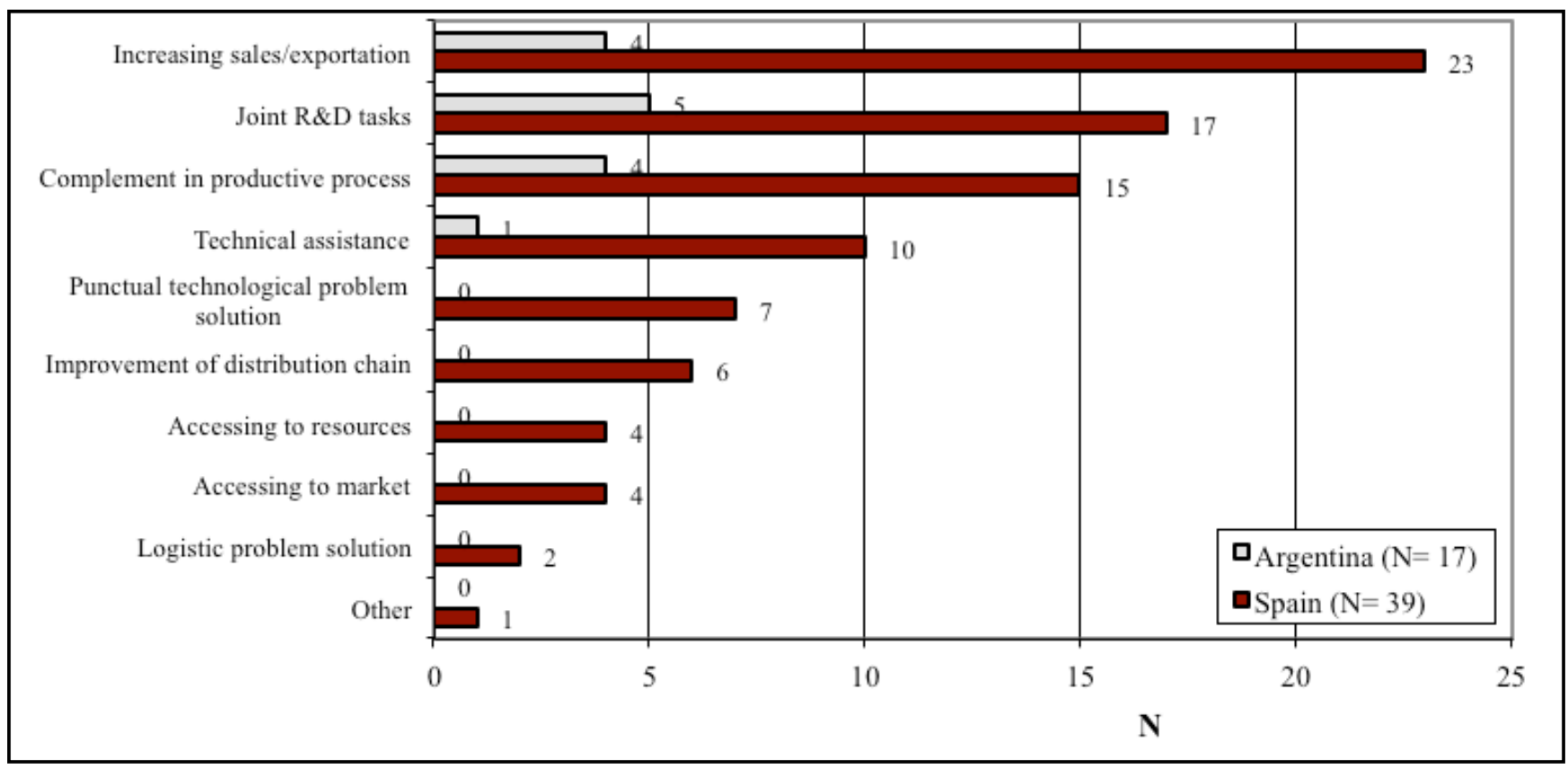

Figure 5. Motives for inter-firm cooperation on R\&D and innovation $(N=56)$

In contrast to the literature on motives for technological cooperation (Hagedoorn, 1993; Bayona et al. ,2001), we observe that access to markets (economic reasons) for Spanish firms is more important than technological reasons (greater focus on R\&D than innovation).

\section{Cooperation process}

Partners and types of cooperation activities involved in R\&D and innovation

Cooperation may be horizontal (between competitors) or vertical (customer, supplier), intra or inter-sectorial. Our results shows that client and supplier firms are the preferred partners for cooperation, with similar participation for both countries: 13 Spanish and 3 Argentine companies, and 12 Spanish and 2 Argentine firms, respectively. Other activities in order of importance are joint R\&D tasks and technology transfer (Table 5). The principal reason for the selection of partners is access to new markets (5 Argentine and 19 Spanish firms), followed by the solutions to technological problems (2 Argentine and 15 Spanish firms) and cultural affinity (3 Argentine and 13 Spanish firms). 


\begin{tabular}{|l|c|c|c|}
\hline \multicolumn{1}{|c|}{$R \& D$ and innovation activities realized in cooperation } & $\begin{array}{c}\text { A rgentine firms } \\
\mathrm{N}=17\end{array}$ & $\begin{array}{c}\text { Spanish firms } \\
\mathrm{N}=39\end{array}$ & Total (N=56) \\
\hline Joint R\&D tasks & $8(47.1 \%)$ & $18(46.2 \%)$ & $26(46.4 \%)$ \\
\hline $\begin{array}{l}\text { K nowledge transference (from Spanish to A rgentine } \\
\text { firms) }\end{array}$ & 0 & $13(33.3 \%)$ & $13(23.2 \%)$ \\
\hline Engineering tasks & 0 & $10(25.6 \%)$ & $10(17.9 \%)$ \\
\hline $\begin{array}{l}\text { Knowledge transference (from A rgentine to Spanish } \\
\text { firms) }\end{array}$ & $9(52.9 \%)$ & 0 & $9(16.1 \%)$ \\
\hline Commercialization improvement & 0 & $7(17.9 \%)$ & $7(12.5 \%)$ \\
\hline Software acquisition & 0 & $6(15.4 \%)$ & $6(10.7 \%)$ \\
\hline Machinery acquisition & 0 & $6(15.4 \%)$ & $6(10.7 \%)$ \\
\hline Formation (capability improvement) & 0 & $4(10.3 \%)$ & $4(7.1 \%)$ \\
\hline Hardware acquisition & 0 & $4(10.3 \%)$ & $4(7.1 \%)$ \\
\hline Consultancy & 0 & $3(7.7 \%)$ & $3(5.4 \%)$ \\
\hline Organization improvement & 0 & $3(7.7 \%)$ & $3(5.4 \%)$ \\
\hline Industrial design & 0 & $3(7.7 \%)$ & $3(5.4 \%)$ \\
\hline
\end{tabular}

Table 5. R\&D and innovation activities realized in cooperation

Table 5 shows that innovation activities are more diversified in the case of Spanish firms and that technology transfer is important for both countries' firms. It is interesting to note that technology transfer occurs in both directions, being located in the group of ITC of Argentine firms.

\section{Agreement types and cooperation frequency}

There are 44 cases of formal agreements between firms (78.6\%). Within the IBEROKA program the most common type of agreement was joint investment (35 firms). It was also the most frequent at the international level, where the local company contributes with capital or knowledge and facilitates access to the market, while the foreign company contributes with capital, brand image or technology. As regards overseas cooperation frequency, only around a third of firms were involved in continuous cooperation (19 firms, 33.9\%) while 24 firms have engaged in cooperation only once (42.9\%) (Table 6).

\begin{tabular}{|l|c|c|c|}
\hline \multicolumn{1}{|c|}{ Cooperation frequency on $R \& D$ and innovation } & $\begin{array}{c}\text { A rgentine firms } \\
\mathrm{N}=17\end{array}$ & $\begin{array}{c}\text { Spanish firms } \\
\mathrm{N}=39\end{array}$ & Total \\
\hline Continuous & 0 & $19(48.7 \%)$ & $19(33.8 \%)$ \\
\hline M ore than 5 times & $1(5.9 \%)$ & $2(5.1 \%)$ & $3(5.4 \%)$ \\
\hline 2 to 5 times & $3(17.6 \%)$ & $7(17.9 \%)$ & $10(17.9 \%)$ \\
\hline One time & $13(76.5 \%)$ & $11(28.2 \%)$ & $24(42.9 \%)$ \\
\hline
\end{tabular}

Table 6. Cooperation frequency on R\&D and innovation 


\section{Public financing support for inter-firm cooperation on R\&D and innovation}

\section{Regulatory conditions and funding}

Governments can facilitate (or not) international collaboration through financial support and easing of the regulatory conditions that restrict the potential for cooperation. Most international activities take place within established international networks and programmes. In general, there are more multilateral programmes and international instruments not integrated with national strategies (Nooteboom, 1999; Hidalgo Nuchera and Albors Garrigós, 2004a; Lundin et al., 2004). The table in the Annex shows that for the total sample and in the case of the Spanish firms the participation in the program IBEROEKA is related to the product improvement ( $P$
$<0.05)$. Table 7 presents the types of public support for financing R\&D and innovation activity: $53.6 \%$ of Spanish firms and approximately the half of the Argentine sample (8 companies, $20.5 \%$ ) received some type of public support for cooperation from the state (and Europe in the case of Spanish firms). Although these are reasonable percentages, real financing conditions differ widely between countries. Argentina is in a less favorable situation due to the generally weak funding support for innovation and the major macroeconomic instability. In Argentina financing of innovation activities depends is essentially down to the individual firms (Kosacoff, 2007).

\begin{tabular}{|l|c|c|c|}
\hline \multicolumn{1}{|c|}{ Public support for cooperation on R\&D and innovation } & $\begin{array}{c}\text { A rgentine firms } \\
\mathrm{N}=17\end{array}$ & $\begin{array}{c}\text { Spanish firms } \\
\mathrm{N}=39\end{array}$ & $\begin{array}{c}\text { Total } \\
(\mathrm{N}=56)\end{array}$ \\
\hline State & $6(35.3 \%)$ & $24(61.5 \%)$ & $30(53.6 \%)$ \\
\hline Europe & - & $8(20.5 \%)$ & $8(20.5 \%)$ \\
\hline IBEROEK A Programme & $7(41.2 \%)$ & $28(71.8 \%)$ & $35(62.5 \%)$ \\
\hline
\end{tabular}

Table 7. R\&D and innovation public supporting

\section{Barrierstointernationalinter-firmcooperation on R\&D and innovation}

Several barriers such as financial restrictions, lack of suitable human resources, results appropriability among partners, additional costs and time of cooperation, finding suitable partners, coordination/communication problems, conflicts of different interests, etc., affect or cause negative impact on cooperation processes (Hladik, 1988; Hagedoorn, 1993; Dodgson; 1992; Hidalgo Nuchera and Albors Garrigós, 2004a,b; Tiwari and Buse, 2007). Interfirm networks are frequently seen as facilitating innovation by being sources of ideas, information and resources. They also can be obstacles to innovation cooperation for technical, knowledge, social and administrative reasons. We can distinguish between internal firm level barriers, from external obstacles. According to the information obtained via the telephone interviews the main difficulties are initiation of the cooperation process, search for partners, and negotiation of agreements. In some sectors -the Chemical industry- the existence of significant differences in normative and regulation conditions is an important obstacle to cooperation. At firm level, the principal obstacle is time taken to produce firm results (14 companies, 25\%), followed by non compliance with the cooperation contract, and the inadequacy human resources (Table 8). 


\begin{tabular}{|l|c|c|c|}
\multicolumn{1}{|c}{ Obstacles at firm level } & $\begin{array}{c}\text { A rgentine } \\
\text { firms } \\
\mathrm{N}=17\end{array}$ & $\begin{array}{c}\text { Spanish } \\
\text { firms } \\
\mathrm{N}=39\end{array}$ & Total (N=56) \\
\hline Time with respect to the concretion of results & $7(41.1 \%)$ & $7(17.9 \%)$ & $14(25.0 \%)$ \\
\hline Lack of fulfillment or infringement by the other party & $1(5.9 \%)$ & $3(7.7 \%)$ & $4(7.1 \%)$ \\
\hline Lack of suitable human resources & $1(5.9 \%)$ & $3(7.7 \%)$ & $4(7.1 \%)$ \\
\hline
\end{tabular}

Table 8. Barriers to cooperation on R\&D and innovation at firm level

Difficulties related to accessing finance and macroeconomic instability, followed by lack of government support and distance between partners were identified as the main obstacles. These results agree with empirical evidence for other countries (Heijs and Buesa, 2006).

\section{Results of the cooperation experience: differences between Argentine and Spanish firms}

\section{Economic and technological results}

We also analysed the results of cooperative innovation obtained by the firms, including economic and technological/innovation results. Similar to the indicators for technological results we considered the percentage of companies that obtained product or process innovations, and the frequency of commercial and organizational innovations, and patents and the licences (Table 9).

\begin{tabular}{|c|c|c|c|}
\hline Cooperation results & $\begin{array}{l}\text { A rgentine firms } \\
\qquad \mathrm{N}=17\end{array}$ & $\begin{array}{c}\text { Spanish firms } \\
N=39\end{array}$ & Total \\
\hline \multicolumn{4}{|l|}{ Product } \\
\hline Product improvements & $3(17.6)$ & $9(23.1 \%)$ & $24(42.9 \%)$ \\
\hline New product introduction & $3(17.6)$ & $23(59.0 \%)$ & $25(44.6 \%)$ \\
\hline Patent (product) & $1(5.9 \%)$ & $1(2.6 \%)$ & $2(3.6 \%)$ \\
\hline \multicolumn{4}{|l|}{ Market } \\
\hline M arket expansion & $2(11.8 \%)$ & $17(43.6 \%)$ & $19(33.9 \%)$ \\
\hline M arket openness & $3(17.6)$ & $13(33.3 \%)$ & $16(28.6 \%)$ \\
\hline \multicolumn{4}{|l|}{ Process } \\
\hline $\begin{array}{l}\text { Increasing of the productive } \\
\text { capacity }\end{array}$ & 0 & $13(33.3 \%)$ & $13(23.2 \%)$ \\
\hline Costs reduction & $1(5.9 \%)$ & $6(15.4 \%)$ & $7(12.5 \%)$ \\
\hline Improvement of human resources & $1(5.9 \%)$ & $3(7.7 \%)$ & $4(7.1 \%)$ \\
\hline Patent (process) & 0 & 0 & 0 \\
\hline Organizational improvement & 0 & $2(5.1 \%)$ & $2(3.6 \%)$ \\
\hline
\end{tabular}

Table 9. Results of the inter-firm cooperation 


\section{Firm satisfaction with the cooperation experiences}

Respondents were asked to estimate the degree to which the specific benefits from cooperation were achieved. Results show that Spanish companies are more optimistic in this regard than Argentina's firms. If we consider satisfaction in terms of cooperation objectives, 13 Spanish firms (33.3\%) and only I Argentine were totally satisfied while 15 Argentine Spanish firms (38.5\%) and 3 Argentine firms (I7.4\%) declared being only partially satisfied. Although half of the companies in the sample said they cooperated frequently and were satisfied with the cooperation experience the degree of importance attributed to the innovation activities involved was described as "high" by only 10 Spanish companies (25.6\%) and 4 Argentine (23.5\%) firms (Table 10).

\begin{tabular}{|c|c|c|c|}
\hline $\begin{array}{l}\text { Importance level of the } \\
\text { innovation activities in } \\
\text { cooperation }\end{array}$ & $\begin{array}{l}\text { A rgentine firms } \\
\qquad \mathrm{N}=17\end{array}$ & $\begin{array}{l}\text { Spanish firms } \\
\qquad N=39\end{array}$ & $\begin{array}{l}\text { Total } \\
\mathrm{N}=56\end{array}$ \\
\hline High & $4(23.5 \%)$ & $10(25.6 \%)$ & $14(25.0 \%)$ \\
\hline M edium & $3(17.6 \%)$ & $10(25.6 \%)$ & $13(23.2 \%)$ \\
\hline Low & 0 & $8(20.5 \%)$ & $8(14.3 \%)$ \\
\hline Irrelevant & $1(5.9 \%)$ & 0 & $1(1.8 \%)$ \\
\hline \multicolumn{4}{|l|}{ Cooperation results } \\
\hline $\begin{array}{l}\text { Firm decides the renovation of } \\
\text { the cooperation agreement }\end{array}$ & $5(29.4 \%)$ & $12(30.8 \%)$ & $17(30.4 \%)$ \\
\hline $\begin{array}{l}\text { Deepening the cooperation } \\
\text { bonds }\end{array}$ & $6(35.3 \%)$ & $12(30.8 \%)$ & $18(32.1 \%)$ \\
\hline $\begin{array}{l}\text { New knowledge was } \\
\text { incorporated to the firm }\end{array}$ & $5(29.4 \%)$ & $10(25.6 \%)$ & $15(26.8 \%)$ \\
\hline $\begin{array}{l}\text { The firm profits have been } \\
\text { incremented }\end{array}$ & $2(11.8 \%)$ & $9(23.1 \%)$ & $11(19.6 \%)$ \\
\hline Patenting/licensing & $1(5.9 \%)$ & $3(7.7 \%)$ & $4(7.1 \%)$ \\
\hline \multicolumn{4}{|l|}{ Firm choose to cooperate again } \\
\hline Y es & $9(52.9 \%)$ & $26(66.7 \%)$ & $35(62.5 \%)$ \\
\hline No & $8(47.1 \%)$ & $13(33.3 \%)$ & $21(37.5 \%)$ \\
\hline
\end{tabular}

Table 10. Importance level of the innovation activities in cooperation 


\section{Conclusion}

This study looked at the phenomenon of cooperative R\&D involving Argentine and Spanish firms, and its interrelationships in order to evaluate the quality of the interactions. We find that the difficulties involved in international inter-firm cooperation over R\&D and innovation activity is not straightforward. Of the more than 100 companies that responded to our survey, chose from a sample of firms most likely to have been involved in innovation and cooperation, only 56 firms had cooperated, 39 in Spain and 17 in Argentina. Although nearly half of these companies had participated in a public program designed to promote cooperation and received financial support, only 35 had engaged in cooperation activities. Argentine firms have less experience of cooperation than do Spanish firms explained in part by the less favourable financing conditions and the less stable macroeconomic context. Around $50 \%$ of Spanish firms cooperate more or less continuously, while $75 \%$ of Argentine firms had cooperated only once.

The information obtained contributes to a better understanding of inter-firm cooperation in two countries which have been overlooked by research and on which and empirical evidence is scarce. This applies especially to high and medium technological intensity SME. We also show, and in contrast to the literature on the motives for technological cooperation, that for the SME in both the countries studied, opportunities from access new markets, launching new products and greater commercialization are major reasons for cooperation. Overall, this study shows that there are some significant differences in the types of cooperation which are based on firm characteristics (size, sector of activity, innovation strategies, R\&D and innovation activities). Differences in the financial mechanisms for supporting R\&D and innovation between Spanish and Argentine firms are an important barrier to cooperation. Information from interviewees shows that the asymmetric distribution and conditions of financial support within the IBEROEKA programme is another major obstacle to successful cooperation initiatives.
The impact of cooperation is more positive for Spanish than for Argentine firms. The latter are less optimistic about the cooperation experience. Thirty per cent of the sample is disposed to renew the cooperation agreements and only in only a few cases had cooperation resulted in new knowledge and increased profits for the firm. Internationalisation of R\&D and innovation constitutes both a challenge and an opportunity for companies and particularly for SME in high and medium high technological sectors. However, this study demonstrates that cooperation does not seem to make a significant difference to firms' innovation capacity. It also does not help to overcome weaknesses in innovation systems. IBEROEKA signifies a relevant effort in the field of science and technology cooperation in Latin America and has contributed to the initiation of a technology cooperation culture. However, new and more efficient funding instruments would be required in order to balance the countries participation in the programme. Policy to support inter-firm cooperation on R\&D and innovation should consider the differences that affect cooperation based on firm specific characteristics and the particular conditions of financing.

\section{Contributions and implications}

The contribution of this paper is providing some empirical evidence on the patterns and barriers to inter-firm cooperation in innovation and R\&D relationships. Both aspects have significant implications for government policy in this area in the specific contexts of Argentina and Spain. The paper finds that the different context conditions impinge upon the pattern, motives and effects of cooperation. These findings call for a differentiated strategy both by the management at firm level and by the incentives set by policy measures. It has to be noted that certain hampering factors which shape the cooperation pattern are caused within the organizations and can be improved by individual management decisions. Yet, other factors shaping the inter-firm cooperation are determined through the national institutional setting and policy framework. This calls for more profound changes and adaptations in the system which will eventually not only lead to easier and more flexible cooperation within the organizations but also to a spread of benefits more broadly in the innovation system. 


\begin{tabular}{|c|c|c|c|c|c|c|c|c|c|c|}
\hline \multicolumn{11}{|c|}{ All firms ( $N=56)$} \\
\hline & $\begin{array}{l}\text { Cooperation } \\
\text { frequency }\end{array}$ & $\begin{array}{l}\text { Funding } \\
\text { (regional) }\end{array}$ & $\begin{array}{l}\text { Funding } \\
\text { (state) }\end{array}$ & $\begin{array}{c}\text { European } \\
\text { Funding }\end{array}$ & $\begin{array}{c}\text { Product } \\
\text { improvement }\end{array}$ & $\begin{array}{c}\text { Market } \\
\text { improvement }\end{array}$ & $\begin{array}{c}\text { Process } \\
\text { imprvement }\end{array}$ & $\begin{array}{c}\text { R\&D and } \\
\text { Innovation } \\
\text { activities }\end{array}$ & $\begin{array}{l}\text { Technology } \\
\text { transfer } \\
\text { from Spain } \\
\text { to Argentina }\end{array}$ & $\begin{array}{c}\text { Technology } \\
\text { transfer from } \\
\text { Argentina to } \\
\text { Spain }\end{array}$ \\
\hline $\begin{array}{l}\text { Years of } \\
\text { activity }^{\text {a }}\end{array}$ & 2,602 & $-0,6$ & $-1,949 *$ & $-0,207$ & $-0,889$ & $-1,853^{*}$ & $-1,086$ & $-0,166$ & $-0,209$ & $-0,557$ \\
\hline Size $^{b}$ & 10,298 & 1,617 & 11,506 & 7,48 & 5,051 & 2,476 & 0,741 & 5,639 & $9,124^{*}$ & 5,972 \\
\hline IBK $^{b}$ & 0,898 & 0,029 & $5,063^{*}$ & 0,689 & $9,009 * * *$ & 1,005 & 1,466 & $4,538 * *$ & $3,341 *$ & 1,646 \\
\hline $\begin{array}{l}\text { Technological } \\
\text { intensity }^{\text {b }}\end{array}$ & 2,504 & 1,213 & 0,464 & 0,643 & 0,835 & 0,262 & 0,722 & 0,637 & 0,935 & 0,48 \\
\hline \multicolumn{11}{|c|}{ Argentina $(\mathrm{N}=17)$} \\
\hline & $\begin{array}{c}\text { Cooperation } \\
\text { frequency }\end{array}$ & $\begin{array}{l}\text { Funding } \\
\text { (regional) }\end{array}$ & $\begin{array}{c}\text { Funding } \\
\text { (state) }\end{array}$ & $\begin{array}{c}\text { European } \\
\text { Funding }\end{array}$ & $\begin{array}{c}\text { Product } \\
\text { improvement }\end{array}$ & $\begin{array}{c}\text { Market } \\
\text { improvement }\end{array}$ & $\begin{array}{c}\text { Process } \\
\text { imprvement }\end{array}$ & $\begin{array}{c}\text { R\&D and } \\
\text { Innovation } \\
\text { activities }\end{array}$ & $\begin{array}{l}\text { Technology } \\
\text { transfer } \\
\text { from Spain } \\
\text { to Argentina }\end{array}$ & $\begin{array}{l}\text { Technology } \\
\text { transfer from } \\
\text { Argentina to } \\
\text { Spain }\end{array}$ \\
\hline $\begin{array}{l}\text { Years of } \\
\text { activity }^{a}\end{array}$ & 3,585 & $-0,507$ & $-0,507$ & & $-0,526$ & $-0,526$ & $-0,742$ & $-0,485$ & & \\
\hline $\operatorname{Size}^{b}$ & 4,452 & 2,404 & 2,769 & & 2,55 & 2,55 & 4,032 & 0,275 & & \\
\hline $\mathrm{IBK}^{\mathrm{b}}$ & 3,516 & 1,409 & 1,409 & & 0,215 & 0,215 & 0,243 & 1,431 & & \\
\hline $\begin{array}{l}\text { Technological } \\
\text { intensity }^{\text {b }}\end{array}$ & 0,18 & 0,215 & 0,215 & & 0,302 & 0,302 & 0,883 & 0,008 & & \\
\hline \multicolumn{11}{|c|}{ Spain ( $N=39$ ) } \\
\hline & $\begin{array}{l}\text { Cooperation } \\
\text { frecquency }\end{array}$ & $\begin{array}{l}\text { Funding } \\
\text { (regional) }\end{array}$ & $\begin{array}{c}\text { Funding } \\
\text { (state) }\end{array}$ & $\begin{array}{c}\text { European } \\
\text { Funding }\end{array}$ & $\begin{array}{c}\text { Product } \\
\text { improvement }\end{array}$ & $\begin{array}{c}\text { Market } \\
\text { improvement }\end{array}$ & $\begin{array}{c}\text { Process } \\
\text { imprvement }\end{array}$ & $\begin{array}{l}\text { R\&D and } \\
\text { Innovation } \\
\text { activities }\end{array}$ & $\begin{array}{l}\text { Technology } \\
\text { transfer } \\
\text { from Spain } \\
\text { to Argentina }\end{array}$ & $\begin{array}{c}\text { Technology } \\
\text { transfer from } \\
\text { Argentina to } \\
\text { Spain }\end{array}$ \\
\hline $\begin{array}{l}\text { Years of } \\
\text { activity }^{a}\end{array}$ & $4,771 *$ & $-0,549$ & $-1,319$ & $-0,683$ & $-0,103$ & $-0,902$ & $-0,061$ & $-0,541$ & $-1,187$ & $-0,43$ \\
\hline Size $^{\mathrm{b}}$ & 9,379 & 2,433 & $14,420 *$ & 4,837 & 4,093 & 0,941 & 1,824 & 7,585 & 7,089 & 4,239 \\
\hline $\mathrm{IBK}^{\mathrm{b}}$ & 2,692 & 1,406 & $9,149 * * *$ & 0,009 & $5,290 * *$ & 0,138 & 0,869 & $3,164 *$ & 1,406 & 0,107 \\
\hline $\begin{array}{l}\text { Technological } \\
\text { intensity }^{\text {b }}\end{array}$ & 3,726 & 1,824 & 0,406 & 1,333 & 0,325 & 1,158 & 0,023 & 0,552 & 1,824 & 0,032 \\
\hline
\end{tabular}

Annex/ a Kruskal-Wallis statistic for cooperation frequency and $U$ de Mann Whitney for the rest of the cases. b Pearson's chi-square $* * * p$-value $<0,01 ; * * p$-value $<0,05 ; *$-value $<0, I$ 


\section{Acknowledgments}

This paper is one of a series of papers in the Project "Estudio Comparado sobre las políticas de Ciencia, Tecnología e Innovación, las interacciones institucionales y las relaciones de cooperación entre Argentina y España" (Comparative Study on Politics of science, technology and innovation, institutional and cooperation interrelationships between Argentina and), supported by CINDOC-CONICET.

\section{References}

AGUERO, E., Suarez, F. And Sebastian, J. (1999). Análisis de la cooperación tecnológica de las empresas españolas con América Latina. Proceedings VIII Seminario Latino Americano de Gestión Tecnológica, ALTEC. Valencia.

ALBORNOZ, M. and Estébanez, M. E. (1998). What do we mean by networking? Selected Latin American Experiences in cooperation. In: New approaches to science and technology cooperation and capacity building, edited by UNCTAD, Geneva.

ARCHIBUGI, D. and Lammarino, S. (2002). The globalization of technological innovation: definition and evidence. Review of International Political Economy, 9(I), 98-I22.

ARCHIBUGI, D. and Michie, J. (1995). The globalization of technology: a new taxonomy. Journal of Economics, I9, I2I-I40.

BARAJAS, A. and Huergo, E. (2006). La cooperación tecnológica internacional en el ámbito de la empresa: una aproximación desde la literatura.CDTI.http://www.cdti.es/

BAYONA, C.; García-Marco, T. And Huerta, E. (200I). Firms' motivations for cooperative R\&D: an empirical analysis of Spanish firms. Research Policy, 30(8), I289-I307.

BINENBAUM, E. (2008). Incentive issues in R\&D consortia: insights from applied game theory. Contemporary Economic Policy, 26(4), 636-650.

BÖNTE, W. and Keilbach, M. (2005). Concubinage or Marriage? Informal and Formal Cooperations for Innovation, International Journal of Industrial Organization, 23, 279-302.
BROCKHOFF, K. (1992). R\&D Cooperation between Firms: A Perceived Transaction Cost Perspective. Management Science, 38, 514-524.

CARLSSON, B. (2006). Internationalisation of innovation systems: A survey of the literature. Research Policy, 35, 56-67

CASSIMAN, B. and Veugelers, R. (1999). Importance of International Linkages for Local Know-How Flows: Some Econometric Evidence From Belgium. Open Access publications from Katholieke Universiteit Leuven. Katholieke Universiteit Leuven.

CDTI (2009). Informe anual 2008. Ministerio de Ciencia e Innovación. http://www.cdti.es/recursos/publicaciones/a rchivos/44789_29102910200994021.pdf

CHILD, J. and Faulkner, D. (1998). Strategies of cooperation: managing alliances, networks, and joint ventures. Oxford University Press.

COMBS, G. and Ketchen, D., Jr. (1999). Explaining interfirm cooperation and performance: toward a reconciliation of predictions from the resource-based and organizational economics. Strategic Management Journal, 20(9), 867-888.

CONNER, K. and Prahalad, C. (1996). A resource-based theory of the firm: knowledge versus opportunism. Organization Science, 7(5), 477-50I.

CRISCUOLO, P. (2004). R\&D Internationalisation and Knowledge Transfer: Impact on MNEs and their Home Countries. PhD Thesis, Universiteit Maastricht, December 2004. http://www.merit.unu.edu/publications/ phd/PCriscuolo.pdf

DAS, T. K. and Teng, B. (2000). Instabilities of strategic alliances: An internal tensions perspective. Organization Science, II(I), 77-I0I.

DAS, T. K. and Teng, B. (2002). A Social Exchange Theory of Strategic Alliances. In Contractor, F. J. and Lorange, P. (2002). Cooperative strategies and alliances. Emerald Group Publishing, pp. 439-4

DE LA MOTHE, J. and Link, A.N. (2002). Networks Alliances and Partnerships in the Innovation Process. Kluwer Academic Publishers, Boston. 
DODGSON, M. (1992). Technological collaboration: problems and pitfalls. Technology Analysis and Strategic Management, 4(I), 83-88.

DUSSAUGE,P.; Garrette, B. And Mitchell, W. (2000). Learningfromcompetingpartners:outco-mesanddurations of scale and link alliances in Europe,North America and Asia.Strategic Management Journal, 2I(2), 99-I26.

EDLER, J. (2007). Internationalisation of R\&D. Empirical trends and challenges for policy and analysis. Policies for research and innovation in the move towards the European Research Area. PRIME 3rd annual conference. Pisa, January 29-February I, 2007.

EDLER, J. (2008). Creative internationalisation: Widening the perspectives on analysis and policy regarding beneficial international R\&D activities. In Edler, J.; Polt, W. (eds.). International Industrial R\&D-the policy challenges-special issue of Journal of Technology Transfer, 33(4), 337-32.

ERIKSSON, P. E. (2007). Cooperation and partnering in facilities construction - empirical application of prisoner's dilemma. Facilities, 25(I/2),7-19.

ERNST, D. (2005). The complexity and internationalisation of innovation: the root causes. Proceedings Globalization of R\&D and Developing Countries. Proceedings of the Expert Meeting Geneva 24-26 January 2005, pp. 6I-88.

EUROSTAT (2010). European Innovation Scoreboard (EIS) 2009. http://www.proinno-europe.eu/metrics

FONFRÍA MESA, A. (1998). Patrones de innovación e internacionalización de las empresas innovadoras españolas. Tesis doctoral. Departamento de Estructura Económica y Economía Industrial. Universidad Complutense de Madrid.

FRITSCH, M. and Lukas, R. (200I). Who cooperates on R\&D? Research Policy, 30, 297-312

GASSMANN, O. and Von Zedtwitz, M. (1999). New concepts and trends in international R\&D organization, Research Policy, 28, 23I-250.

GERWIN, D. and Meister, D. (2002). Coordinating new product development in an international joint venture. International Journal of Technological Management, 24, 27-43.
HAGEDOORN, J. (1990). Organizational modes of interfirm co-operation and technology transfer. Technovation, 10(I), 17-30.

HAGEDOORN, J. (1993). Understanding the rationale of strategic technology partnering: inter-organizational modes of cooperation and sectoral differences. Strategic Management Journal, I4, 37I-385.

HAGEDOORN, J. (1996). Trends and patterns in strategic technology partnering since the early seventies. Review of Industrial Organisation, II, 60I-616.

HAGEDOORN, J. (2002). Inter-firm R\&D partnerships: An overview of major trends and patterns since 1960. Research Policy, 3I, 477-492.

HAGEDOORN, J. and Osborn, R. N. (2002). Interfirm R\&D partnerships: Major theories and trends since 1960. In Contractor,F.J.AndLorange,P.(2002). Cooperativestrategies and alliances. Emerald Group Publishing, pp. 517-542.

HAGEDOORN, J. And Schakenraad, J. (1994). The effect of strategic technology alliances on company performance. Strategic Management Journal, 15(4), 29I-309.

HAGEDOORN, J., Link, A.N. And Vonortas, N.S. (2000). Research partnerships. Research Policy, 29, 567-586.

HEIJS, J. and Buesa, M. (Eds.). (2006). La cooperación en innovación en España, el papel del estado. Instituto de Estudios Fiscales. España.

HIDALGO NUCHERA, A. And Albors Garrigós, J. (2004a). La internacionalización de la tecnología a través de los proyectos de innovación IBEROEKA. Cuadernos de Economía y Dirección de la Empresa, 20, 57-82.

HIDALGO NUCHERA, A. and Albors Garrigós, J. (2004b). Success factors and hindrances in international $R \& D$ cooperation programmes. The case of IBEROEKA. 13th International Conference on Management of Technology. Washington, D.C. USA.

HIDALGO NUCHERA, A.; Aldana, F.; Albors Garrigós, J. And Scheuneman, I. (2006). International science and technology cooperation and development programs. An evaluation of the CYTED program in the Latin America area. IAMOT 2006. 
HLADIK, K. (1988). R\&D and International Joint Ventures. En Contractor, F.J. and Lorange, P. (Eds.). Cooperative strategies in international business, Lexington Books, Lexington, Massachusetts, pp. 187-203.

HOFFMANN, W. H. and Schlosser R. (200I). Success Factors of Strategic Alliances in Small and Medium-sized Enterprises-An Empirical Survey. Long Range Planning. 34(3), 357-38I.

INDEC (2008). ENIT (Encuesta Nacional sobre Innovación y Conducta Tecnológica, ENIT 2005). Buenos Aires. INDEC. http://www.indec.mecon.ar/nuevaweb/ cuadros/16/publicacion-enit-2005.pdf

INE (2009). Encuesta de Innovación. Madrid.

KAUSER, S. and Shaw, V. (2004). International Strategic Alliances: objectives, motives and success. Journal of Global Marketing, 17(2/3), 7.

KHANNA, T., Gulati, R. And Nohria, N. (1998). The dynamics of learning alliances: competition, cooperation, and relative scope. Strategic Management Journal, 19(3), 193-22I.

KOSACOFF, B. (2007). Crisis, recuperación y nuevos dilemas: la economía argentina 2002- 2007. CEPAL. Buenos Aires.

LÓPEZ SEBASTIÁN, A. (2008). Determinants for R\&D Cooperation: Evidence from Spanish Manufacturing Firms. International Journal of Industrial Organization, 26(I), II3-136.

LUNDIN, P.; Frinking, E. And Wagner, C. (2004). International collaboration in R\&D. Structure and dynamics of private sector actors. Gaia Group Oy. Helsinki.

MOLERO, J. (1998). Pattems of intemationalization of Spanish innovatory firms. Research Policy, 27 (5), 54I-558.

MONTORO, M. A.; Mora, E. And Guerras, L. A. (2006). $R \& D$ cooperative agreements between firms and research organizations.Acomparativeanalysis of thecharacteristicsand reasons depending on the nature of the partner., International Journal of Technological Management, 32, |56-|8|.
NARULA, R. (2002).R\&D collaboration by SMEs: some analytical issues and evidence. In Contractor, F. J. and In Contractor, F. J. and Lorange, P. (2002). Cooperative strategies and alliances. Emerald Group Publishing, Pp. 439-460.

NARULA, R. (2004). R\&D collaboration by SMEs: new opportunities and limitations in the face of globalisation. Technovation, 24(2), I53-16I.

NARULA, R. and Duysters, G. (2004). Globalisation and trends in international R\&D alliances. Journal of International Management, 10(2), 199-218.

NIOSI, J. (1999). The internationalisation of industrial R\&D. From technology transfer to the learning organization. Research Policy, 28, 107-II7.

NIOSI, J. and Reid, S. E. (2007). Biotechnology and Nanotechnology: Science-based Enabling Technologies as Windows of Opportunity for LDCs? World Development, 35(3), 426-438.

NOOTEBOOM, B. (1999). Inter-firm alliances: analysis and design. Routledge. USA. Canada.

OECD (2008). The Internationalisation of Business R\&D: Evidence, Impacts and Implications. OECD.

OECD (2009). Innovation in Firms. A Microeconomic Perspective. OECD.

PORTER, M.E. (1980). Competitive Strategy. Free Press, New York.

PIETROBELLI, C. (1996). Emerging forms of technological cooperation: the case of technology partnership. New York and Geneva: United Conference on Trade and Development.

SANNA-RANDACCIO, F. And Veugelers, R. (200l). Multinational Knowledge Spillovers with Centralized versus Decentralized R\&D: A Game-theoretic Approach. CEPR Discussion Papers, 3.15I.

SIVADAS, E. and Dwyer, F. R. (2000). An examination of organizational factors influencing new product success in internal and alliance-based processes. Journal of Marketing, 64(I), 3I-49. 
TEIXEIRA, A. C.; Santos, P. And Brochado, A. O. (2008). International R\&D Cooperation between low-tech SMEs: the role of cultural and geographical proximity. European Planning Studies, 16(6), 785-810.

TEECE, D. J. (1987). Profiting for technological innovation. Implications for integration, collaboration, licensing, and public policy. In Teece, D. J. (Ed.). The competitive challenge. Ballinger, Cambridge, M. A., pp. 185-220.

TETHER, B.S. (2002). Who co-operates for innovation, and why. An empirical analysis. Research Policy, 3I, 947-967.

TIWARI, R. and Buse, S. (2007). Barriers to Innovation in SMEs: Can the Internationalisation of R\&D Mitigate Their Effects? Conference on Corporate R\&D (Concord). Hamburg University of Technology (TUHH).

VEGA JURADO, J.; Gutiérrez Gracia, A. And Fernández De Lucio, I. (2008). ¿Cómo innovan las empresas españolas? Una evidencia empírica. Journal of Technology Management and Innovation, 3(3), I00-III.

VONORTAS, N. (1997). Research joint ventures in the U.S. Research Policy, 26 (4-5), 577-595.

VONORTAS, N.; Caloghiorou, Y. And loadbides, S. (2003). Research Joint Ventures: A Critical Survey Of theoretical and empirical literature. Journal of Economics Surveys, 17, 54I. 
J. Technol. Manag. Innov. 20II,Volume 6, Issue 3 